\title{
Evaluating On-going ESP Courses at Two Higher Education Institutions: Students' Perspectives
}

\author{
Luluk Iswati ${ }^{1, *}$ Saptin Dwi Setyo Hastuti ${ }^{2}$ \\ ${ }^{1}$ Universitas Muhammadiyah Yogyakarta \& Yogyakarta State University \\ ${ }^{2}$ AMPTA Tourism College \& Yogyakarta State University \\ *Email: luluk007@gmail.com
}

\begin{abstract}
As ESP is increasingly applied in many non-English departments of higher education institutions, evaluating the course is pivotal as it gauges to what extent the program is successful to meet learners' needs and the overall course goals. Hence, this study was set out to evaluate on-going ESP courses held in two private higher education institutions in Yogyakarta Province by evaluating three aspects: the ESP teachers, the course materials, and the course. The data were collected through an online survey of 149 students of Universitas Muhammadiyah Yogyakarta (UMY) and AMPTA Tourism College and processed with descriptive statistics. Overall, the results suggested that both institutions' students agreed that the three aspects met the set criteria, yet some implications worth take into account. Concerning the ESP practice at the Management Study Program of UMY, sub-aspects that needed improvement were teachers' monitoring during students' activities, the distribution of language skills in the materials, and the variety of learning activities. In the context of the Tour and Travel Business Study Program of AMPTA Tourism College, it demanded attention to teachers' preparedness before teaching, the skills and knowledge relatedness to students' future jobs, and the classroom size.
\end{abstract}

Keywords: ESP Evaluation, Higher Education

\section{INTRODUCTION}

Having been increased in importance in the last few decades, ESP teaching in the non-English department of tertiary education is considered a better approach for EFL learners. Owing to its more specific learning goals, which are prescribed based on learners ${ }^{\text {ee }}$ analysis, the ESP course is deemed more effective than the general English course [1]. The process of running an ESP course entails a complex procedure consisting of, among others, conducting needs analysis, designing the syllabus, preparing the relevant materials, and evaluating the program. Evaluation in ESP is crucial as it is a way to measure the extent to which the course's goal is met, what went right, and what needs fixing. In other words, evaluation measures how successful the course is.

However, due to the short period of ESP courses usually held, the literature on ESP evaluation is still rare [2]. Moreover, evaluating the ESP course is not an easy task [3] because several things need to be taken into account, such as what aspects and how they are evaluated, what tool is used to collect data, what action needs to be carried out after evaluation, and so on. Evaluating a language course can be done periodically during the course or at the end of the program [4]. There have been many studies in the areas of ESP, but the research that focuses on evaluating an ESP course is still limited, and the evaluation was usually conducted at the end of the course held by a single institution [2], [5]-[10]. To fill this void, this study was set out to evaluate ongoing ESP courses from learners' point of view in two private higher education institutions in Yogyakarta Province, namely Universitas Muhammadiyah Yogyakarta and AMPTA Tourism College. The two institutions were selected because the ESP teachers in both institutions reportedly had a high concern in improving ESP courses' quality at their institutions. Referring to [6], three major aspects of ESP were used as the evaluation basis: the teachers, the course materials, and the course. Thus, the research questions of this study are as follows:

1. How do ESP learners perceive their ESP teachers' teaching performance?

2. How do ESP learners view the ESP course materials?

3. How do ESP learners see the ESP course in their institutions? 


\section{LITERATURE REVIEW}

\subsection{ESP Course Evaluation}

Hutchinson \& Waters, as cited in [3], assert that in ESP courses, evaluation criteria are rendered even more relevant by the fact that such courses usually set specific goals. It is to say that determining aspects for evaluation should refer to the prescribed learning objectives [4]. It can consist of "the course's goals, the course content, the needs assessment, the way the course is organized, the materials and methods, the learning assessment plan, and the course evaluation plan." Evaluating a language course can be used as a basis for decisions making [4]. Teachers can decide the necessary actions to improve the course or other related aspects. The evaluation also serves as a platform to gauge the overall usefulness and feasibility of an employed syllabus [11] so that parts of the syllabus (the course materials) that work well with the intended learners and which ones need adjustment or replacement can be identified.

\subsection{Review of Previous Studies}

ESP course evaluation studies have been carried out in different parts of the world. A study undertaken by [5] evaluated an ESP course for engineering students in an Iranian university to find out whether the course was helpful for students' future jobs. A questionnaire was distributed to employees who worked in a similar field as the students. The study implied the need for materials closely related to technological advancement for communication among engineering students, which heavily emphasized reading resources. Although the study was beneficial for their target learners, the results might not be applicable to different contexts. Its sole focus on the course materials could not be used to measure the course's effectiveness as a whole.

Meanwhile, [6] evaluated an ESP course in a Turkish university under three major aspects: the teachers, the materials, and the course. Having students as the respondents, the results revealed that learners were highly satisfied with the ESP teachers' performance and the materials used, yet they showed moderate satisfaction on the course. Despite an indepth discussion and interpretation of the results, the study seems to ignore its limitation.

In Warsaw, [7] evaluated a blended ESP course for instrumentalists, which consisted of several phases. The evaluation involved the process of analyzing learners' needs, determining the course objectives and materials, and conducting a formative evaluation. The results indicated the course's success particularly related to how the assessment was objectively conducted and how learners perceived it. What [7] failed to address was the evaluation of how his study's results fit in or contradicted previous studies.

A study undertaken by [2] proposed a comprehensive framework of an ESP course evaluation conducted in Taiwan. The evaluation framework consisted of three major aspects - the course, learner assessment, and teacher participation and empowerment. Data were collected by surveying students, distributing the questionnaire to teachers, and assessing students' learning achievement through the TOEIC test. The framework turned out to be less practical as it consisted of too many elements generated from the three major aspects that should be measured at once.

A study in Malaysia evaluated an ESP online class as a complement for a face-to-face interaction [12]. It was conducted with 23 undergraduate students of English for Science and Technology course. It revealed that students' response towards the course was positive despite some technical problems. Although the study showed a strong theoretical foundation, students' evaluation of the online course material might not perfectly represent what they perceived on the whole materials given during the whole course as it only evaluated a passage.

\subsection{Framework of the Study}

Concerning the present study, three aspects developed by [6] were employed as a framework to conduct the evaluation, including ESP teachers, ESP course materials, and ESP course. They would be evaluated from the students' point of view.

\subsubsection{ESP Teachers}

[13] highlight two main domains that belong to teacher cognition as an attempt to get an understanding of ESP teachers" practices. The domains are decision making and teacher knowledge. [13] add that decision making mainly refers to what materials to select. As cited in [13], Tsui points out teachers' decisions during in-class interaction, which relates to what languages classes should be used. Ferguson, as cited in [13], urges three areas of ESP knowledge: knowledge related to the disciplinary culture, knowledge on different disciplines, and knowledge about linguistic areas, such as genre and discourse.

\subsubsection{ESP Course Materials}

ESP teaching resources have been considered one of the very prominent issues among ESP teachers [14]-[18]. [15] asserts that the ESP course is developed to open the way for students for their future job situation. Therefore, the materials should be highly related to students' field of study and not be emphasized only on particular language skill. Lan, as cited in [15], avers that ESP courses should provide speaking and writing materials as the two 
skills significant for ESP learners' language development. Vocabulary also plays a significant component in ESP materials as it should be specific and relevant to learners [19]-[22]. To enhance learners" vocabulary acquisition, receptive skills (reading and listening) should also be taught.

Learners need to be exposed to their related field vocabularies, but they should not be given in isolation. Thus, through reading and listening, ESP learners learn vocabulary contextually. Reading and listening are essential skills in ESP materials [23][26]. Further, pronunciation should be considered part of ESP course materials as it will contribute to learners" speech intelligibility. Some researchers include it to be one aspect in their ESP studies [27][29]. If taught successfully, pronunciation can decrease potential problems [30]. Grammar, although usually given very little attention in ESP course, should be considered as it may provide useful implications for ESP learners [31]

\subsubsection{ESP Course}

Several aspects are worth considering when conducting ESP classes: the adequacy of learning hours, ample individual, pair, group work activities, and proper physical classroom size [6]. Class hours become essential in ESP courses as the program is usually held in a shorter period or weighs fewer credits. Activities should be various as learners need to practice the situational language functions with their peers and communicate in a simulated situation [32]. The classroom needs to be given attention as an over-capacity class can affect the teaching-learning process's effectiveness.

\section{METHODOLOGY}

This study employed a quantitative method to get a snapshot of two institutions' on-going ESP courses (Tour and Travel Business Study Program of AMPTA Tourism College and Management Study Program of UMY). Utilizing a google form, the questionnaires were disseminated to the semester two students of both institutions, and 174 students finally participated in the study. The questionnaire was adapted from that of [6], and it encompassed 28 items under three aspects of evaluation - the ESP teachers, the ESP course, and the ESP teaching and learning process. A 4-point Likert scale was adopted under the category of Strongly Disagree (1), Disagree (2), Agree (3), and Strongly Agree (4). The 4-point Likert scale was used to avoid a neutral response toward each item. To ensure the validity of the adapted instrument, five colleagues were requested to validate it. This study was conducted after students took mid-term tests hoping that they had got enough learning experience as a basis to evaluate the course. Thus, this study was an on-going course evaluation rather than an end-of-course evaluation. The data were processed using SPSS 22 and analyzed descriptively.

\section{RESULTS}

This section presents the results of data collected through questionnaires and calculated using SPSS 22. The data interpretation was based on mode, representing phenomena and the highest and lowest frequency of categorized aspects presented in percentage (\%). A mode is the value of data that has a high frequency of occurrence. Of 174 students who submitted the questionnaire, 149 were UMY students, while the other 24 were AMPTA students. The data presentation is divided into three primary domains: the ESP teachers, the ESP course materials, and the course.

\subsection{Students' evaluation of ESP teachers}

Regarding students' evaluation of ESP teachers' performance during teaching, students should evaluate ten aspects. The results of students' evaluation of ESP teachers are displayed in the following tables.

Table 1. UMY students' evaluation of ESP teachers $(n=149)$

\begin{tabular}{|l|l|c|c|c|c|c|}
\hline \multirow{2}{*}{ No } & \multirow{2}{*}{ The ESP teachers: } & \multirow{2}{*}{ Mode } & \multicolumn{4}{|c|}{ Frequency (\%) } \\
\cline { 5 - 7 } & & & $\mathbf{1}$ & $\mathbf{2}$ & $\mathbf{3}$ & $\mathbf{4}$ \\
\hline 1 & are well-prepared & 3 & 1.7 & 6.9 & 64.1 & 27.3 \\
\hline 2 & master the subject-matter knowledge & 3 & 2 & 4 & 62.5 & 31.5 \\
\hline 3 & give adequate explanation when answering students' questions & 3 & 1.3 & 6.7 & 69.2 & 22.8 \\
\hline 4 & monitor during students' learning activities & 3 & 6.7 & 2 & 73.5 & 17.8 \\
\hline 5 & present the materials effectively & 3 & 1.3 & 8.1 & 67.8 & 22.8 \\
\hline 6 & make effective transition between materials & 3 & 1.3 & 8.1 & 73.8 & 16.8 \\
\hline 7 & link the materials with each other & 3 & 2 & 12.1 & 61.7 & 24.2 \\
\hline 8 & communicate effectively with students & 3 & 1.3 & 3.4 & 78.5 & 16.8 \\
\hline 9 & use effective teaching method & 3 & 0.7 & 0 & 79.8 & 19.5 \\
\hline 10 & direct students' attention to the lesson being learned. & 3 & 0.7 & 1.3 & 75.2 & 22.8 \\
\hline
\end{tabular}


The table above shows UMY students' evaluation of their teachers' performance during teaching. The ten statements had mode 3, which indicated that students gave positive responses to teachers' overall performance. It denoted that, in general, the ESP teachers at UMY had done the ten activities above. Of the aspects that gained positive responses, teachers' well-preparedness was dominant (27.3\% strongly agree). However, in every statement, there was a negative response with a small percentage.
It illustrated that a small number of students perceived that the teachers had not fulfilled those roles optimally. Of the ten aspects to which students responded negatively, monitoring students' learning activities gained the most frequent negative response (6.7\% strongly disagree). Meanwhile, the data obtained from AMPTA students concerning their evaluation of ESP teachers' performance is exhibited in the table as follows:

Table 2. AMPTA students' evaluation of ESP teachers $(n=24)$

\begin{tabular}{|l|l|c|c|c|c|c|}
\hline \multirow{2}{*}{ No } & \multirow{2}{*}{ The ESP teachers: } & \multirow{3}{*}{ Mode } & \multicolumn{3}{|c|}{ Frequency (\%) } \\
\cline { 3 - 6 } & & $\mathbf{1}$ & $\mathbf{2}$ & $\mathbf{3}$ & $\mathbf{4}$ \\
\hline 1 & are well-prepared & 3 & 8.3 & 0 & 70.9 & 20.8 \\
\hline 2 & master the subject-matter knowledge & 3 & 0 & 0 & 45.8 & 54.2 \\
\hline 3 & give adequate explanation when answering students' questions & 3 & 0 & 0 & 70.8 & 29.2 \\
\hline 4 & monitor during students' learning activities & 3 & 0 & 8.3 & 75.0 & 16.7 \\
\hline 5 & present the materials effectively & 3 & 0 & 0 & 66.7 & 33.3 \\
\hline 6 & make effective transition between materials & 3 & 0 & 0 & 79.2 & 20.8 \\
\hline 7 & link the materials with each other & 3 & 0 & 0 & 62.5 & 37.5 \\
\hline 8 & communicate effectively with students & 3 & 0 & 8.3 & 70.9 & 20.8 \\
\hline 9 & use effective teaching method & 3 & 0 & 4.2 & 66.7 & 29.1 \\
\hline 10 & direct students' attention to the lesson being learned. & 3 & 0 & 0 & 58.3 & 41.7 \\
\hline
\end{tabular}

As exhibited in Table 2, AMPTA students' responses toward their teachers' performance were also positive since the mode was 3 . It signified that most students admitted that ESP teachers at AMPTA had performed the ten duties above. Teachers' mastery of the subject matter gained the highest positive score (54.2\% strongly agree). Only a few did not agree that the teachers were well-prepared, monitored the learning activities, communicated effectively with the students, and used effective teaching methods. Among the few negative responses, teachers' preparedness in teaching gained the most negative value ( $8.3 \%$ strongly disagree).

\subsection{Students' evaluation of the course materials}

Referring to the course materials, five aspects were evaluated, and the results can be seen in the table as follows:

Table 3. UMY students' response towards the course materials $(n=149)$

\begin{tabular}{|l|l|c|c|c|c|c|}
\hline \multirow{2}{*}{ No. } & \multirow{2}{*}{ The course materials: } & \multirow{3}{*}{ Mode } & \multicolumn{2}{|c|}{ Frequency (\%) } \\
\cline { 3 - 6 } & $\mathbf{1}$ & $\mathbf{2}$ & $\mathbf{3}$ & $\mathbf{4}$ \\
\hline 1 & are appropriate for students' field of study & 3 & 1.3 & 0.7 & 73.8 & 24.2 \\
\hline 2 & are of quality (contain educational value and strength) & 3 & 1.3 & 4.7 & 74.5 & 19.5 \\
\hline $\begin{array}{l}\text { contain the skills and knowledge that students need for their future } \\
\text { occupation }\end{array}$ & 3 & 1.3 & 4 & 78.5 & 16.2 \\
\hline 4 & contain language suitable for students' level of language competency & 3 & 2 & 4 & 71.2 & 22.8 \\
\hline 5 & contain adequate: & & & & & \\
\hline & a. reading skill & 3 & 0.7 & 8.7 & 75.2 & 15.4 \\
\hline & b. listening skill & 3 & 2 & 8.1 & 81.8 & 8.1 \\
\hline & c. grammar & 3 & 0.7 & 8.1 & 76.5 & 14.8 \\
\hline
\end{tabular}




\begin{tabular}{|l|l|c|c|c|c|c|}
\hline d. writing skill & 3 & 0.7 & 2.7 & 74.5 & 22.1 \\
\hline & e. vocabulary & 3 & 0.7 & 4 & 74.5 & 20.8 \\
\hline f. speaking skill & 3 & 1.3 & 3.4 & 81.9 & 13.4 \\
\hline g. pronunciation skill & 3 & 1.3 & 3.4 & 76.5 & 18.8 \\
\hline
\end{tabular}

Table 3 reveals UMY students' evaluation of the ESP course materials. The mode value of the 11 statements above was 3 , meaning that students gave positive responses toward the course materials in a general sense. Alternatively, overall, the course materials were suitable for students at the Management Study Program of UMY. Most students responded positively to the materials' appropriateness with students' field of study ( $24.2 \%$ strongly agree). However, few students thought that the materials had not met the criteria above, as indicated by a small percentage of negative responses to every statement, especially the adequacy of language skills that the course materials provided. From all language aspects of language skills, listening was the most inadequate (2\% strongly disagree). Meanwhile, the data collected from AMPTA students regarding their evaluation of the course materials are displayed in table 4 as follows:

Table 4. AMPTA students' response towards the course materials $(n=24)$

\begin{tabular}{|l|l|c|c|c|c|c|}
\hline No. & The course materials: & \multirow{2}{*}{ Mode } & \multicolumn{4}{|c|}{ Frequency (\%) } \\
\cline { 4 - 7 } & & & $\mathbf{1}$ & $\mathbf{2}$ & $\mathbf{3}$ & $\mathbf{4}$ \\
\hline 1 & are appropriate for students' field of study & 3 & 0 & 4.2 & 58.3 & 37.5 \\
\hline 2 & are of quality (contain educational value and strength) & 3 & 0 & 0 & 58.3 & 41.7 \\
\hline 3 & $\begin{array}{l}\text { contain the skills and knowledge that students need for their future } \\
\text { occupation. }\end{array}$ & 3 & 4.2 & 12.5 & 79.1 & 4.2 \\
\hline 4 & contain language suitable for students' level of language competency & 3 & 0 & 29.2 & 58.3 & 12.5 \\
\hline 5 & contain adequate: & & & & & \\
\hline & a. reading skill & 3 & 0 & 25 & 62.5 & 12.5 \\
\hline & b. listening skill & 3 & 0 & 29.2 & 58.3 & 12.5 \\
\hline & c. grammar & 3 & 0 & 20.8 & 66.7 & 12.5 \\
\hline & d. writing skill & 3 & 0 & 20.8 & 41.7 & 37.5 \\
\hline & e. vocabulary & 3 & 0 & 25 & 62.5 & 12.5 \\
\hline & f. speaking skill & 3 & 0 & 8.3 & 83.4 & 8.3 \\
\hline & g. pronunciation skill & 3 & 0 & 4.2 & 75 & 20.8 \\
\hline
\end{tabular}

The data above shows how AMPTA students evaluated the course materials. The overall result showed a positive response as the mode value was 3 . It indicated that the course materials given to AMPTA students were generally appropriate. The aspect that students responded positively the most was the quality of course materials, which contained educational values and strengths $(41.7 \%$ strongly agree). Nevertheless, some aspects were valued negatively. The most apparent negative response was given to statement no.4, meaning that a few students did not agree that the course materials contained adequate skills and knowledge needed by students for their future occupation (4.2\% strongly disagree). Some also did not agree that the materials contained adequate reading, listening, grammar, writing, and vocabulary skills. Listening was the most inadequate skill (29.2\% disagree). Meanwhile, only a few students did not agree that the materials contained enough speaking (8.3\% disagree) and pronunciation skills ( $4.2 \%$ disagree).

\subsection{Students' evaluation of the course}

The third aspect of evaluation is evaluating the course. Under this aspect, students responded to six aspects, as seen in the table below. 
Table 5. UMY students' response towards the course $(n=149)$

\begin{tabular}{|c|l|c|c|c|c|c|}
\hline \multirow{2}{*}{ No } & \multirow{2}{*}{ The ESP course: } & \multirow{3}{*}{ Mode } & \multicolumn{4}{|c|}{ Frequency (\%) } \\
\cline { 3 - 6 } & & & $\mathbf{1}$ & $\mathbf{2}$ & $\mathbf{3}$ & $\mathbf{4}$ \\
\hline 1 & has clear learning outcomes & 3 & 1.3 & 0.7 & 81.2 & 16.8 \\
\hline 2 & is given in an adequate hours/duration/meeting & 3 & 0.7 & 0.7 & 77.2 & 21.5 \\
\hline 3 & is held in adequate classroom size & 3 & 0.7 & 2.7 & 77.2 & 19.5 \\
\hline 4 & gives an opportunity for students to work in pairs & 3 & 1.3 & 2 & 75.8 & 20.8 \\
\hline 5 & gives opportunity for students to work in group & 3 & 0.7 & 4 & 75.8 & 19.5 \\
\hline 6 & gives an opportunity for students to work individually & 3 & 1.2 & 2.9 & 75.1 & 20.8 \\
\hline
\end{tabular}

Shown in Table 5, the data revealed that overall, the ESP course at the Management Study Program of UMY was responded positively. The mode was 3, indicating that the response was positive or showed that the course was carried out well. Nevertheless, of the six statements, four responded negatively by a very small percentage of students. It disclosed that only a small number of students thought that the course had not met the criteria described in the table. The most frequent positive response was given to the adequate hours/duration/meetings of the course $(21.5 \%$ strongly agree), while the most negative response concerned with adequate opportunity to do activities through pair works (1.3\% strongly disagree). Concerning AMPTA students' evaluation in the course, it can be seen in the following table

Table 6. AMPTA students' response towards the ESP course $(n=24)$

\begin{tabular}{|l|l|c|c|c|c|c|}
\hline No & The ESP course: & Mode & \multicolumn{3}{|c|}{ Frequency (\%) } \\
\cline { 3 - 6 } & & $\mathbf{1}$ & $\mathbf{2}$ & $\mathbf{3}$ & $\mathbf{4}$ \\
\hline 1 & has clear learning outcomes & 3 & 0 & 4.2 & 75 & 20.8 \\
\hline 2 & is given in adequate hours/duration/meetings & 3 & 0 & 0 & 70.8 & 29.2 \\
\hline 3 & is held in an adequate classroom size & 3 & 4.2 & 16.7 & 62.5 & 16.7 \\
\hline 4 & gives opportunity for students to work in pairs & 3 & 0 & 4.2 & 75 & 20.8 \\
\hline 5 & gives opportunity for students to work in group & 3 & 0 & 4.2 & 75 & 20.8 \\
\hline 6 & gives opportunity for students to work individually & 3 & 0 & 0 & 87.5 & 12.5 \\
\hline
\end{tabular}

The data displayed in the table above describes students' responses on the ESP course at Tour and Travel Business of AMPTA Tourism College. Similar to the previous domains, in general, it showed a positive response, indicating that the teaching and learning process ran well. Of the six criteria, however, the two aspects that gained no negative response were the adequacy of hours/duration/meetings that the course offered (29.2\% strongly agree and $70.8 \%$ agree) and the opportunity for students to work individually (12.5\% strongly agree and $87.5 \%$ agree). Meanwhile, classroom size got the most negative response among other sub-aspects (4.2\% strongly disagree), signifying that quite many students did not agree that the course was held in adequate classroom size.

\section{DISCUSSION}

The overall results of evaluating the teachers in both institutions indicated a positive response. In UMY, the highest positive response was teachers" preparedness, while in AMPTA, it was valued as the most negative aspect. It showed that for some students, the teachers in AMPTA were not well-prepared when teaching. This finding is in line with previous studies on ESP that highlight ESP teachers' preparedness as an issue in teaching [33]-[35]. Lack of preparedness in teaching might imply teachers' heavy teaching load and tight schedule that result in inadequate time for teaching preparation [36]. Some ESP researchers have found that it is common for ESP teachers to teach too many classes with too many students [36]-[39]. Thus, teaching becomes a very energy-consuming activity. This finding calls for attention from the respective institution to have a closer look at the teaching schedule assigned to each teacher so that it allows teachers to have enough time to prepare before teaching.

Though the frequency was not significant, UMY students' negative response towards teachers' monitoring should be considered during the learning activities. Owing to a significant number of students (40 to 45) in one class, monitoring closely individual student's learning activity, especially their learning pace, was not an easy task. Teachers had to struggle hard when they gave equal attention to each student. This finding implied that having a smaller class size should be considered to monitor students' participation during the learning activities more efficiently. Thus, students who were still weak in certain areas could be 
easily identified, and the necessary help could be given. Difficulty in monitoring students' learning progress was also found in an earlier ESP study by [40]. Monitoring students' work is part of classroom management to ensure students' participation during class activities. Monitoring students' interaction is a phase in the working process during the lesson [41]. To ease monitoring, the room should be organized to allow enough space for teachers to walk around [42].

Surprisingly, concerning teachers' subject-matter knowledge, students from both institutions gave positive responses. In other words, teachers found no obstacles when delivering materials not related to their educational background. This finding contradicts many ESP studies that found the lack of teachers' knowledge of students' field of study [14], [25], [33], [43]. Teachers' mastery of subject-matter knowledge might indicate that they had made themselves familiar with students' field of study or been given training before started their ESP teaching. Students' field of studies might have been considered by teachers as being not too difficult or too foreign for them. Therefore, they probably did not need to put too much effort into getting themselves into students' study fields.

Besides, concerning the course materials, most students of AMPTA and UMY reported that they agreed on the materials in line with their field of study, the field of Management (for UMY students), and Tour and Tourism Business (for AMPTA students). It is concurrent with a study conducted by [44], who found that the coursebook contents are related to students' specialty. Hence, it can be said that materials appropriateness for students' particular field had been met. Strevens in [45] stated that materials relatedness with students' discipline is one of ESP course's major characteristics. Regarding students' responses regarding the materials' quality, all AMPTA students gave positive responses, which indicated that the teachers might have carefully selected and developed the materials to meet learners' needs. Yet, some UMY students gave quite frequent negative response towards it, indicating that the materials had not contained educational values and strong points from their perspective.

Of the skills and knowledge, most students at both institutions seemed highly valued at both institutions, although a few disagreed that the skills and knowledge contained in the materials were needed for their future occupations. In AMPTA, for example, it was regarded as the only negative aspect evaluated by the students. Language skills and knowledge of specific disciplines had long been considered in ESP studies. [5] revealed that materials related to students' future jobs are needed for ESP students. [34] explained that students learn ESP to obtain and improve their knowledge in their field and their language skills. Concurrent with this, [46] pointed out that for a successful ESP course to take place, knowledge on a specific field and English language skills should go together. The less suitability of language skills and knowledge in ESP course with students' specialty knowledge might indicate that needs analysis should be done more properly so that learners' needs in language skills related to their future career can be accommodated.

In conjunction with the language used in the materials, most students at both colleges agreed that its level or complexity was suitable for their competency, although many students at AMPTA disagreed. Thus, the teachers need to have a closer look again on the materials to ensure that it does not contain language complexity, which is beyond students' capability to understand, or on the other hand, not too easy or not challenging. [47] found that low language capability students would find the content activities hard to tackle. As students' language capacity varies, teachers can make sure the materials accommodate students' various languageproficiencies.

Regarding the adequacy of the language skills taught, students at both institutions valued speaking as the highest, meaning that this productive skill was dominantly taught in their ESP courses. This finding partly supports Lan et al., as cited in [15], who suggested that two crucial skills that should be taught are speaking and writing in ESP courses. On the other hand, listening gained the most negative response from UMY students, meaning that this skill was not adequately taught. This finding is concurrent with [36], who found that ESP students in their study context learned very limited listening skills. Thus, it might be inferred that this skill was given less priority to teaching in ESP courses.

Dealing with the ESP course, overall, both institutions' students gave positive responses to it, although few aspects needed to be given more attention. The highest positive response of both institutions was the adequacy of hours/duration/meetings of the course. It indicated that what was prescribed in the course syllabus could be enacted in the given teaching duration or number of class meetings. In a general sense, it might be said that students perceived the course materials to be doable within the allocated time, and the density of the materials was not beyond students' ability to accomplish. It might also imply that the materials were concurrent with the credit load of the course. This finding supports a study by [48].

As for the various learning activities, both institutions' students mostly agreed that the course allowed them to have activities in the group, in pairs, and individually. However, some UMY students did not agree that the teaching-learning process gave them enough chance to work in pairs and groups with their classmates. It could lead to an assumption that the tasks prescribed in the coursebook or designed by the teachers required the students to work more on an individual basis or in groups. The importance of varying the types of class activities support [20], [49], [50]. The usefulness of pair work for students was found in [20], which revealed that students had a high preference for pair work activities. Similarly, [50] found out that students preferred active learning activities through pair, group, and individual activities. 
Concerning the classroom size, not all students agreed that the course was held in an adequate classroom. In fact, students of AMPTA showed a quite high percentage of disagreement towards this aspect. Although some students of UMY also showed disagreement on this aspect, the frequency was not as high as that of AMPTA. Finding related to inadequate classroom size is in line with the study of [6], which showed students' dissatisfaction with the physical size of ESP classroom as there were too many students, and the classroom size was too small. The lack of appropriate physical size demands attention from the respective institutions to facilitate a convenient teaching and learning environment to help achieve the course goals.

\section{CONCLUSION AND IMPLICATIONS}

The evaluation of ESP courses among Management students of UMY and Tour and Travel Business students of AMPTA, which focused on three major domains - the ESP teachers, the course materials, and the teaching-learning process - revealed positive results. Regarding the three aspects, the ESP courses in the two private institutions were wellperceived by the students. Although positive responses in all aspects were dominant, few negative responses can serve as feedback towards the betterment of ESP courses in both institutions. Concerning ESP teachers at UMY, monitoring students' learning activities should be enhanced to help those who encounter obstacles. Meanwhile, it is necessary for AMPTA teachers to improve their preparedness in teaching so that the teaching process can run smoothly and effectively. Of the course materials, it is essential to reckon skills and knowledge to ensure its benefits for students' future occupations, especially for AMPTA students. Also, the language level of difficulty needs to be adjusted with students" current level of language competence. In the context of UMY, the distribution of language skills should be evaluated so that they support the achievement of students' communicative skills in ESP settings. Concerning the ESP course in AMPTA, those in charge should pay attention to the classroom size as the learning environment is a crucial aspect that can contribute to learning success. As for the ESP course in UMY, various learning activities are necessary so that tasks can be accomplished by students more effectively, and they can experience the learning process through individual, pair, and group works.

\section{REFERENCES}

[1] H. Basturkmen, Developing courses in English for Specific Purposes. New York: Palgrave Macmillan, 2010.

[2] W. Tsou and F. Chen, "ESP program evaluation framework: description and application to a Taiwanese university ESP program," English
Specif. Purp., vol. 33, no. 1, pp. 39-53, 2014, doi: $10.1016 /$ j.esp.2013.07.008.

[3] A. H. Hatam and S. Shafiei, "The evaluation of the effectiveness of ESP courses in enhancing technical translation proficiency: A case study of ESP course for mechanical engineering students," English Lang. Teach., vol. 5, no. 5, pp. 68-78, 2012, doi: 10.5539/elt.v5n5p68.

[4] K. Graves, Designing language courses: A guide for teachers. Boston, Massachusetts: Heinle \& Heinle Publishers, 2000.

[5] Z. Amirian and M. Tavakoli, "Reassessing the ESP Courses Offered to Engineering Students in Iran ( A Case Study)," English Specif. Purp. World, vol. 8, no. 23, 2009, [Online]. Available: http://esp-world.info/.

[6] H. Çelik, "A closer look into an ESP course through students' end-of-course evaluations: a case study," J. Teach. English Specif. Acad. Purp., vol. 6, no. 1, p. 125, 2018, doi: 10.22190/jtesap1801125c.

[7] E. D. Lesiak-Bielawska, "English for Instrumentalists : Designing and Evaluating an," English Specif. Purp. World, vol. 15, no. 43, 2014.

[8] M. Salehi, "Comparative Effect of Scaffolding Instruction and Self-Regulated Learning on ESP Learners" Reading Comprehension," no. May, pp. 203-213, 1998.

[9] H. Salehi, A. Davari, and M. Md Yunus, "Evaluation of an ESP course of Qur'anic sciences and tradition," Int. Educ. Stud., vol. 8, no. 1, pp. 29-37, 2015, doi: 10.5539/ies.v8n1p29.

[10] M.-D. N. So'ud, "Evaluation of ESP Course Designed to First Year, Sudanese Law Students, Alneelain University From the Students' Perspective," J. Humanit., vol. Vol .17 ., no. 1, p. 11, 2016, doi: 10.1101/112268.

[11] U.-O. Nneka and O. Ada, "An evaluation of English for Specific Purposes (ESP) as a modern trend in English Language Teaching (ELT)," African Res. Rev., vol. 8, no. 3, p. 179, 2014, doi: 10.4314/afrrev.v8i3.15.

[12] T. S. Ming and L. Bidmeshki, "Evaluating Malaysian Science and Technology undergraduates' reactions towards an online ESP Course," CALL-EJ Online, vol. 7, no. 2, pp. 1-19, 2006. 
[13] H. D. Wu and R. G. Badger, "In a strange and uncharted land: ESP teachers' strategies for dealing with unpredicted problems in subject knowledge during class," English Specif. Purp., vol. 28, no. 1, pp. 19-32, 2009, doi: 10.1016/j.esp.2008.09.003.

[14] M. Estaji and N. Nazari, "Exploring Instructors' Conceptions about EGP Teacher Challenges for Becoming an ESP Instructor in Iran: A Qualitative Study," vol. 46, no. 46, pp. 1-18, 2015.

[15] Y. Khoshhal, "The Role of Teaching Materials in the ESP Course: A Case of Business English (Finance and Economics).," J. Humanist. Soc. Stud., vol. 9, no. 1, p. 85, 2018, [Online]. Available: http://www.diglib.um.edu.my/interaktif/default. asp?url=http://search.ebscohost.com/login.aspx? direct $=$ true $\& \mathrm{db}=\mathrm{edb} \& \mathrm{AN}=131211477 \&$ site $=\mathrm{ed}$ s-live.

[16] N. Medrea and D. Rus, "Challenges in teaching ESP: teaching resources and students' needs," Procedia Econ. Financ., vol. 3, no. 12, pp. 1165-1169, 2012, doi: 10.1016/s22125671(12)00291-2.

[17] D. Poedjiastutie, "The Pedagogical challenges of English for Specific Purposes (ESP) teaching at the University of Muhammadiyah Malang, Indonesia.," Educ. Res. Rev., vol. 12, no. 6, pp. 338-349, 2017, doi: 10.5897/ERR2016.3125.

[18] B. Setiawati, "Needs analysis for identifying ESP materials for medial record students in APIKES Citra Medika Surakarta," Kaji. Linguist. dan Satra, vol. 1, no. 1, pp. 61-72, 2016.

[19] L. Anusienė, L. Kaminskienè, and G. Kavaliauskienè, "The Challenges for ESP Learners: Alternative Assessment of Performance and Usefulness of Class Activities," Kalbu Stud., no. 10, pp. 75-81, 2007.

[20] J. Gass, "Needs analysis and situational analysis: designing an ESP curriculum for Thai nurses," English Specif. Purp. World, vol. 12, no. 36, pp. 1-21, 2012.

[21] A. S. Rijal, "English Learning Strategy By Applying Cr Strategy for Esp Class," in The Fourth International Seminar on English Language Teaching (ISELT-4), 2016, no. 2012, pp. 54-61.
[22] B. Xhaferi, "Teaching and learnig ESP vocabulary," LFE Rev. lenguas para fines específicos, vol. 1127, no. 15, pp. 229-255, 2009.

[23] H. I. Aldohon, "English for Specific Purposes (ESP) for Jordanian tourist police in their workplace: needs and problems," Int. Educ. Stud., vol. 7, no. 11, pp. 56-67, 2014, doi: 10.5539/ies.v7n11p56.

[24] M. Aliakbari and M. Boghayeri, "A Needs Analysis Approach to ESP Design in Iranian Context," Procedia - Soc. Behav. Sci., vol. 98, pp. 175-181, 2014, doi: 10.1016/j.sbspro.2014.03.404.

[25] A. Arifuddin, A. Arafiq, I. M. Sujana, and K. Apgriyanto, "The Mastery of and Strategies for Understanding the Idiomatic Expressions Applied by the Students of Hospitality and Tourism," J. Hosp. Tour. Educ., vol. 00, no. 00, pp. 1-11, 2019, doi:

10.1080/10963758.2019.1685392.

[26] A. Dabaghi and M. Akvan, "Explore the relationship between strategy use and ESP reading test performance of two university majors (humanities VS. science)," Theory Pract. Lang. Stud., vol. 4, no. 1, pp. 121-128, 2014, doi: $10.4304 /$ tpls.4.1.121-128.

[27] K. C. Li, Khe Liew \& Pey, "ESP at Tertiary Level : Traditional ESP or Integrated ESP?," Symp. Int. Lang. Knowl. (SiLK 2014), 14th-16th Feb 2014 was held Hydro Hotel. Penang Organ. by Cent. Int. Lang. Univ. Malaysia Perlis., 2014, [Online]. Available: http://dspace.unimap.edu.my/dspace/bitstream/1 23456789/34587/1/GENERAL PAPER_3.pdf.

[28] E. Saragih, "Designing ESP materials for nursing students based on needs analysis," Int. J. Linguist., vol. 6, no. 4, pp. 59-70, 2014, doi: 10.5296/ijl.v6i4.5983.

[29] U. Trisyanti, "Developing materials for ESP (English for Specific Purposes) class," J. Sos. Hum., vol. 2, no. 1, pp. 66-77, 2009, doi: 10.12962/j24433527.v2i1.666.

[30] B. M. Grandyna, “A university EFL teacher's strategies in solving the teaching pronunciation problems," J. Foreign Languange Teach. Learn., vol. 3, no. 2, 2018, doi: $10.18196 / \mathrm{ft} 1.3232$. 
[31] Z. Chen, "Grammar Learning Strategies Applied to ESP Teaching," Theory Pract. Lang. Stud., vol. 6, no. 3, p. 617, 2016, doi: 10.17507/tpls.0603.23.

[32] N. N. Prudnikova, "ESP Teaching at the institutions of higher education in modern Russia: problems and perspective," in Bulgarian Comparative Education Society Conference Book, 2013, pp. 390-396, doi: $10.2139 /$ ssrn.2232203.

[33] D. Alsharif and N. Shukri, "Exploring pedagogical challenges of ESP teachers at a Saudi Arabian university," Int. J. Asian Soc. Sci., vol. 8, no. 10, pp. 841-855, 2018, doi: 10.18488/journal.1.2018.810.841.855.

[34] M. Bracaj, "Teaching English for Specific Purposes and teacher training," Eur. Sci. J., vol. 10, no. 2, pp. 40-49, 2014.

[35] K. Chung-chien Chang, "From Eap To Esp: a Teacher'S Identity Development," Taiwan J. TESOL, vol. 14, pp. 71-100, 2017.

[36] N. T. T. Hoa and P. T. T. Mai, "Difficulties in teaching English for Specific Purposes: empirical study at Vietnam universities," High. Educ. Stud., vol. 6, no. 2, pp. 154-161, 2016, doi: 10.5539/hes.v6n2p154.

[37] V. Bhatia, L. Anthony, and J. Noguchi, "ESP in the 21 st century: ESP theory and application today," 2011.

[38] Kusni, "Reformulating English for Specific Purposes (ESP) in Indonesia: current issues and future prospects," in SELT 2013 Proceeding, 2013, pp. 36-48.

[39] A. Marwan, "ESP teaching challenges in an Indonesian vocational higher institution," English Teach., vol. XXXVIII, no. 0, pp. 1-12, 2017.

[40] H.-I. Hou, "A needs analysis of culinary arts majors' ESP learning in Taiwan's context," Asian ESP J., vol. 9, no. 3, pp. 5-34, 2013, [Online]. Available: http://www.asian-espjournal.com.

[41] G. Szepe, "Linguistic aspects of intercultural communication," in An international perspective on language policies, practices and proficiencies, vol. 37, no. 2, D. E. Ingram, D. Cunningham, and A. Hatoss, Eds. Belgrave: FIPLV, 2010, pp. 1-420.
[42] M. C. Clement and M. C. Clement, "Four steps to classroom management after spring break," Educ. Horizons, vol. 92, no. 3, pp. 28-29, 2019.

[43] S. Čepon, “Teachers' and students' perspectives on the reasons for speaking anxiety in English for specific purposes," ESP Today, vol. 4, no. 2, pp. 184-201, 2016, doi:

10.18485/esptoday.2016.4.2.3.

[44] M. Ahmadvand, H. Barati, and S. Ketabi, "Rights analysis of ESP courses : towards democratizing ESP education," English Specif. Purp. World, no. 46, pp. 1-13, 2015, doi: 10.1016/j.physb.2015.03.023.

[45] W. Zhu and D. Liu, "Study on the Theoretical Foundation of Business English Curriculum Design Based on ESP and Needs Analysis," High. Educ. Stud., vol. 4, no. 1, pp. 68-74, 2014, doi: 10.5539/hes.v4n1p68.

[46] B. H. Nguyen, P. Haworth, and S. Hansen, "Challenging ESP teacher beliefs about active learning in a Vietnamese university," Teach. Dev., vol. 23, no. 3, pp. 345-365, 2019, doi: 10.1080/13664530.2019.1598481.

[47] K. Gatehouse, "Key issues in English for specific purposes (ESP) curriculum development," Internet TESOL J., vol. VII, no. 10, pp. 1-10, 2001, [Online]. Available: http://iteslj.org/Articles/Gatehouse-ESP.

[48] S. Kaur and A. B. M. A. Khan, "Language needs analysis of art and design students: considerations for ESP course design," ESP World, vol. 9, no. 2 (28), 2010, doi: 10.1017/CBO9781107415324.004.

[49] R. A. Gestanti, E. P. Nimasari, and R. Mufanti, "ESP Issue in Indonesian tertiary context: what students need in learning English," PUPIL Int. J. Teaching, Educ. Learn., vol. 3, no. 1, pp. 98117, 2019, doi: 10.20319/pijtel.2019.31.98117.

[50] S. A. Boroujeni and F. M. Fard, "A needs analysis of English for Specific Purposes (ESP) course for adoption of communicative language teaching : a case of Iranian first-year students of educational administration," Int. J. Humanit. Soc. Sci. Invent., vol. 2, no. 6, pp. 35-44, 2013, [Online]. Available: www.ijhssi.org. 